\title{
Standardisation and heritage language maintenance: preliminary interdisciplinary considerations with a case-based approach
}

\author{
Estandarización y mantenimiento del patrimonio lingüístico: \\ consideraciones interdisciplinares preliminares \\ desde un enfoque basado en casos
}

\author{
Mattia Zeba \\ University of Trento \\ mattia.zeba@unitn.it
}

doi: http://dx.doi.org/10.18543/djhr.1899

Submission date: 26.02 .2020

Approval date: 06.11.2020

Citation/Cómo citar: Zeba, Mattia. 2020. «Standardisation and heritage language maintenance: preliminary interdisciplinary considerations with a case-based approach». Deusto Journal of Human Rights, No. 6: 211-238. doi: http://dx.doi.org/10.18543/djhr.1899.

Summary: Introduction: towards a hybrid approach. 1. Linguistic variation and the process of standardisation. 2. Dynamics of standardisation in a transnational context: new opportunities. 3. Dynamics of re-standardisation in a transnational context: a matter of choice. Conclusion: from a hybrid understanding to a hybrid practice. References.

\begin{abstract}
Over the last few decades, emerging hybrid understandings of multilingualism and language belonging have contributed to a more inclusive perspective on language rights and policies. However, it is still debated how similar challenging views on language itself can also contribute to constructing inclusive policies of language maintenance, especially in a kaleidoscopic linguistic landscape such as that shaped by migratory phenomena. Against this background, this paper highlights a series of preliminary considerations regarding the interlocking dynamics among standardisation processes, language variation and international migration. Through an analysis of several relevant cases, it aims to identify how a hybrid understanding of language and its internal variation can contribute to a more effective, sensible and inclusive perspective on heritage language maintenance.
\end{abstract}

Keywords: language, minority rights, new minorities, interdisciplinarity, language maintenance, migration. 
Resumen: A lo largo de las últimas décadas, las perspectivas híbridas emergentes del multiculturalismo y la pertenencia lingüística han contribuido a una aproximación más inclusiva sobre los derechos lingüísticos y las políticas. Sin embargo, todavía se plantea cómo estimulantes puntos de vista similares sobre la lengua en sí pueden contribuir también a la construcción de políticas inclusivas de mantenimiento del idioma, especialmente en un paisaje lingüístico caleidoscópico como el generado por los fenómenos migratorios. Frente a este contexto, este artículo destaca una serie de consideraciones preliminares sobre las dinámicas interrelacionadas entre los procesos de estandarización, la variación lingüística y la migración internacional. A través del análisis de varios casos relevantes, tiene como objetivo identificar cómo una perspectiva híbrida del lenguaje y su variación interna puede contribuir a una más efectiva, sensible e inclusiva perspectiva sobre el mantenimiento del patrimonio lingüístico.

Palabras clave: lengua, derechos de las minorías, nuevas minorías, interdisciplinariedad, mantenimiento lingüístico, migración. 


\section{Introduction: towards a hybrid approach}

In the last few decades, there has been a shift towards a much more inclusive perspective on language rights and policies. As stated by the Advisory Committee on the Framework Convention for the Protection of National Minorities, "inclusive language policies should cater for the needs of everybody, including persons belonging to national minorities living outside their traditional areas of settlement, immigrants and non-citizens" (ACFC 2012, 13). In such a context of increasing "super-diversity" (Vertovec 2007), an inclusive approach implies moving beyond territoriality, personality, and given minority labels to recognise the dynamism and blurriness of such concepts, which have too often been formulated as static categories. As reflected in the working definition of the concept of 'minority', "a person can freely belong to an ethnic, religious or linguistic minority without any requirement of citizenship, residence, official recognition or any other status" (UNHRC 2020, 70). Furthermore, assumptions about linguistic justice, understood in the multiculturalist sense of "protecting the rights of minority groups" (Alcalde 2018, 70), have slowly been disentangled from historical and territorial criteria in order to support solutions that can address the needs of 'new' and 'old' minorities alike. Indeed, it has been argued that "in today's increasingly diverse societies it would be conceptually meaningful and beneficial in terms of diversity governance to widen the scope of minority rights traditionally conceived for old, historical minorities [...] to new minorities originating from migration" (Marko and Medda-Windischer 2018, 281).

Against this background, debates in the fields of education, political philosophy and minority rights are shifting away from the idea of linguistic diversity as an emergency, thus embracing multilingualism as the rule. Firstly, this trend translates into the adoption of a functional 'holistic' approach to bilingualism, which is based on the actual use of more than one language in daily life rather than on pluri-linguistic competence in often monocultural environments (Grosjean 1989; Cenoz and Gorter 2014). Secondly, the spread of hybrid language ideologies (De Schutter 2007) factors in "significant levels of individual bilingualism in a demos, as well as the coexistence of individuals with different linguistic abilities and different patterns of linguistic identity" (Riera 2016, 54). Thirdly, there has been a shift from the so-called 'threat-hypothesis' -that is "the belief that historical groups frequently perceive large-scale migration as a danger and harbour defensive and exclusionary attitudes towards migrants" (Medda-Windischer and Carlà 2015, 4)_, to a much more inclusive and open approach that emphasises that "old and new 
minorities share some common characteristics and thus voice similar claims" (Medda-Windischer 2017, 32).

In addition, the debate on the subjective criterion and on the principle of self-identification has arguably given rise to a right of self-identity (Craig 2016), which eventually implies recognising that individuals can show a sense of belonging to multiple identities. Indeed, cultures may be seen as objects of choice including "the additional options of multiple membership and toleration of syncretic and hybrid practices that mix elements from different cultures" (Bauböck 1996, 209) in successive, cumulative and continuous relations. This cosmopolitan approach (Waldron 1992) has been endorsed by the Advisory Committee on the FCNM with regard in particular to language: indeed, "a person may also identify himself or herself in different ways for different purposes, depending on the relevance of identification for him or for her in a particular situation"; furthermore, "a person may claim linguistic rights with regard to several minority languages, as long as the relevant conditions, such as demand and/ or traditional residence, contained in the respective articles of the Framework Convention are fulfilled" (ACFC 2012, para 18).

Similarly, although with an even more fluid approach, the Ljubljana Guidelines on Integration of Diverse Societies state that "individual identities can be and in fact increasingly are multiple (a sense of having several horizontal identities; for instance, belonging to more than one ethnicity), multi-layered (various identities coexist and overlap in the same person, such as ethnic, religious, linguistic, gender, professional and the like), contextual (the context might determine which identity is more prominent at a given moment) and dynamic (the content of each identity and the attachment of individuals to it is changing over time)" (OSCE HCNM 2012, 4).

Therefore, hybrid understandings of multilingualism and language belonging have been adopted and advocated by most authors and disciplines as a welcomed development towards a more inclusive approach to language maintenance, understood as "the continuing use of a language in the face of competition from a regionally and socially powerful or numerically stronger language" (Mesthrie 1999, 42 ) or "the continued use or retention of an L1, a minority or heritage language in one or more spheres of language use" (Pauwels 2016, 20). Indeed, in an increasingly superdiverse and globalising world, monoglossic/discrete ideologies are not able to grasp the multitude of socio-linguistic outcomes in situations of language contact, nor are they able to respond to the linguistic needs and claims stemming from our modern societies, where multiple languages and identities coexist. 
Nevertheless, it has been (and still is) debated how a more 'relativist' perspective on language itself may contribute to the protection and promotion of minority and minoritised languages. As identities have been increasingly accepted as multiple, multi-layered, contextual and dynamic, so the notion of language has deeply changed since the structuralist view of language "as a static and delimited entity, an object which could be captured, codified and thus standardised" (Lane 2015, 266). From post-modern theorists to language ecologists, language has been re-discovered as a socially constructed system in a constant development driven by an ever-changing environment (Haugen 1972, Wright 2018). With regard, in particular, to the field of language policy and planning, the focus has shifted from the myth of standardised languages to the macro and micro-dynamics of the process of standardisation. However, accepting the fluid nature of language - that is, its diachronic and synchronic variation - is not directly equal to fostering more fair, efficient and inclusive language policies. Indeed, although the interaction between the processes of standardisation and language maintenance has been widely studied, there is not yet agreement on how to balance the recognition of variation with the implementation of solid, effective and democratic policies. Furthermore, most of the debate, especially in Europe, has focused on the so-called 'old minority languages' or autochthonous languages, often overlooking standardisation dynamics in contexts of immigration.

The first reason for such a bias regards the conceptual blurriness of the 'languages of immigrants'. Indeed, the term itself cannot convey the complex spatio-temporal dynamics of migratory phenomena. Therefore, different authors and disciplines have adopted similar but not equivalent definitions. For instance, the linguistic debate has distinguished between 'migrant languages' (Bagna et al. 2003), used in contexts characterised by a high degree of individual mobility and of local fluctuations, and 'immigrant languages' (Panzeri 2016), which identifies those instances where a real and solid immigrant community shows "a long-lasting, if not definitive, migratory project" (Orioles 2007, 331) in a given territory. Other authors (Trifonas and Aravossitas 2018) instead have used terms such as 'languages of origin' (Makarova 2014), 'ethnic languages' (Saint-Jacques 1979), 'community languages' (Wiley 2005), 'home languages' (Yeung et al. 2000) or simply 'mother tongues'. Finally, in the field of education, the term 'heritage languages' has been gaining consensus since the 1970s to define in general "language spoken by the children of immigrants or by those who immigrated to a country when young" (Cho et al. 
2004, 23), and in particular "the incompletely learned home language arising from the phenomenon of language shift and the switch to the dominant language that is characteristic in the case of immigrants and their descendants" (Trifonas and Aravossitas 2018, 4; Polinsky and Kagan 2007).

The second issue regards the linguistic characteristics and the legalpolitical context of these languages -subsequently referred to simply as 'heritage languages'. Even if they are grouped together under the same label because of their shared dynamics with migration phenomena, heritage languages may be former colonial languages, global lingua francas, official 'national' languages, emigrated 'old minority' languages, unrecognised languages or unstandardised systems of dialect continua. From a perspective of language maintenance, each of these manifestations may require different measures of protection and promotion. Clearly, there are very complex reasons behind these differences, ranging from numerical weight, to economic appeal, from political relations to discriminatory patterns. However, a seminal issue is their internal linguistic variation and its relationship with the dynamics of migration.

This paper highlights a series of preliminary considerations regarding standardisation processes, language variation and heritage language maintenance with a case-based approach. Firstly, it focuses on definitions and analyses general issues related to standardisation. Secondly, it focuses on the dynamics between standardisation and migratory phenomena, showing how these processes may relate to each other. Thirdly, it analyses how linguistic variation and destandardisation processes may be influenced by the kaleidoscopic environment shaped by international migrations. The final aim of the paper is to identify how a hybrid understanding of language can contribute to the adoption of a more inclusive perspective on language rights and policies.

\section{Linguistic variation and the process of standardisation}

Language is characterised by the existence of variants, which may have a social or geographic dimension. On the one hand, "each social group, no matter how small, that identifies itself as a social group develops speech patterns that set it apart from every other social unit" (Hallen and Linn 1984, 237). On the other hand, almost every language has its own geographic variants or dialects. In contrast, the notion of languages as independent discrete systems with clear-cut boundaries 
is deeply linked, especially in Europe, with the modern processes of nation-building, as clearly depicted by Wright $(2015,115)$ :

Most Europeans spoke languages which belonged to dialect continua (Romance, Germanic, Slavic, etc.), and at the beginning of the modern period, the linguistic landscape is best described as overlapping isoglosses with no clear linguistic demarcation lines on the continuum. The boundaries came as linguists engaged in what Kloss (1967) termed Ausbau. As national languages were codified and standardised, the aim was to achieve maximum linguistic convergence within the national group and maximum linguistic differentiation from other neighbouring (national) groups (Milroy and Milroy 1985).

Therefore, although the difference between 'language' and 'dialect' may be of a "purely relative nature" (Bloomfield 1933, 54; Haugen 1966), the process of relabelling 'dialects' as 'languages' —and consequent standardisation - may be understood mainly as the result of a political choice: it has indeed been famously argued that "a language is a dialect with an army and a navy" (Weinreich 1945, 13; Maxwell 2018). Furthermore, such processes are also fostered by instrumental economic considerations: "just as the proliferation of varying coinages or weights and measures is dysfunctional, so a proliferation of different forms of the language would be highly undesirable in a society that requires widespread communications" (Milroy 2006, 134).

In socio-linguistic terms, standardisation has been defined as "the process of one variety of a language becoming widely accepted throughout the speech community as a supradialect norm - the 'best' form of the language- rated above regional and social dialects, although these may be felt to be appropriate in some domains" (Ferguson 1996, 189). Consequently, standardised languages, though "unnatural" and "pathological in their lack of diversity" (Hudson $1980,34)$, have been described as "superordinate language varieties representing in one way or another correct or prestigious linguistic usage" (van Wyk 1992, 25). According to Milroy and Milroy (1985) standardisation comprises seven stages, which are not necessarily sequential: selection, acceptance, diffusion, maintenance, elaboration of function, codification and prescription. Each of these stages may be initiated and carried out by different actors in the society, a factor that also influences the outcome of the process. For instance, as will be seen, the involvement of external actors or experts may hamper the stage of acceptance by native speakers because the end-product 
would feel as a 'foreign invention' (Jones 1995). Finally, standardisation affects different features of language at various stages: grammar, spelling, word choice, pronunciation and script.

However, it would be wrong to conceive of 'standards' as an end-state. Instead, standardisation is a process in which linguistic uniformity is never achieved: In fact, "the standard variety will contain its own variations, both synchronically and diachronically" (Pillière and Lewis 2018, §24), while "it seems appropriate to speak more abstractly of standardisation as an ideology, and a standard language as an idea in the mind rather than a reality -a set of abstract norms to which actual usage may conform to a greater or lesser extent" (Milroy and Milroy 1985, 19). Furthermore, standard languages are mostly and primarily written languages (Slaughter 1982). Indeed, this feature highlights their link to the nation-building process, since there seems to be an indissoluble link between written language and nationalism, as exemplified by Anderson's debated theory of print capitalism (Anderson 1983).

The process of standardisation may have significant advantages for a given language community. With regard to its instrumental reasons, it offers a common framework of linguistic norms that simplify communication between a wider set of users; furthermore, a 'standard language' better suits mainstream education since it reduces the costs of training teaching staff and elaborating didactic materials by widening the target group. With regard instead to identity-related justifications, it has been argued (Wardhaugh 2006, 34-35) that the standardisation process

unifies individuals and groups within a larger community while at the same time separating the community that results from other communities. Therefore, it can be employed to reflect and symbolize some kind of identity: regional, social, ethnic, or religious. A standardized variety can also be used to give prestige to speakers, marking off those who employ it from those who do not, i.e., those who continue to speak a nonstandard variety.

For these reasons, standardisation has acquired a crucial role especially in the process of minority language maintenance (Jones 1995). In fact, "a prescriptive standard, frequently in conjunction with some degree of legal recognition, is often the weapon of choice in struggles to resist minority status and marginalisation" (Costa et al. 2017, 11). The recognition of minority language rights may entail minority language education, widespread use of the minority 
language in the public administration and/or the establishment of minority language media. Consequently, the implementation of language policies in these fields fosters language standardisation by grouping together a larger share of users. Instead, it has been argued that "where we find acceptance of linguistic variation among the component parts of a group perceived as a minority, we will mostly find that speakers have minimal language rights" (Wright 2018, 648). In other words, the implementation of minority language rights may both require and promote the process of language standardisation. More debatably, it has also been speculated that wider processes of nation-building may trigger smaller processes of minority resistance through standardisation: "engulfed by the language of another country, the variety spoken by the minority speech community has a better chance of surviving if it can be perceived by its speakers as being on a par with that of the larger speech community in terms of its functional domains" (Jones 1995, 424).

In order to better clarify the dynamics analysed so far, it may be useful to briefly analyse the case of Ladin education in Trentino (Italy). Ladins are an ethnic group of the Dolomite mountains that inhabits the valleys between the autonomous provinces of Bolzano (South Tyrol) and Trento (Trentino), as well the province of Belluno in the Veneto region. Due to these administrative divisions, Ladin communities enjoy different levels of minority protection, the highest being in South Tyrol and the lowest in Veneto. With regard to the Ladins of Trentino, mainly living in the Fassa valley, they enjoy educational language rights according to art. 102 of the 1972 Statute of autonomy. All the schools are thus reunited under a common authority -la Sorastanza de la scoles ladines de Fascia. In these schools, Ladin is both taught as a curricular subject and used to teach other subjects, although mainly in the elementary schools and for a limited number of teaching hours. There is neither a standard form of Ladin, though there have been attempts to come up with one, nor a standard form of Fassan Ladin, which is itself divided into three subgroups-cazet, brach and moenese. However, due to historical and sociolinguistic reasons, the cazet variant has been chosen as a written standard in administrative communication and, more importantly, in schools. Although it would arguably have been impossible, or at least highly ineffective, to develop a common educational system and common teaching materials without a shared and sufficiently accepted written standard, oral variants are still used at all levels - particularly to teach other subjects - and sometimes actually in open contrast to a perceived process of standardisation (Rasom 2011). 
The Ladin case is useful to highlight the first problem regarding standardisation and language maintenance. The choice of the cazet variant has been influenced by different non-Ladin actors, mainly scholars and linguists. Such external intervention has brought about a feeling of alienation by native Ladin speakers (Wright 2007). Indeed, "it is also possible that standardization -especially if it is not carried out with the active participation of speakers and close attention to their needs and interests - might actually accelerate the gradual disappearance of the complex spoken language ecologies which keep unstandardized languages alive" (Deumert and Vandenbussche 2003, 464).

However, not every external intervention translates into language loss. Furthermore, it would be a misconception to understand standardisation as a process pertaining exclusively to written language so that every language would be clearly divided into local variants used in intracommunal domestic/local oral interactions and standardised languages in intercommunal state/global written ones. Indeed, (semi-)standardised variants may emerge also between the majority-official-standard language and local non-standardised dialects either as a response to top-down pushes or bottom-up processes, as in the case of Tussentaal in the Flemish region of Belgium. Literally meaning in-between-languages, Tussentaal is not yet a single language "but a whole range of unique constellations of dialectal and standard variants determined by speech situation, education type, age, sex, and regional background" (Delarue and De Caluwe 2015, 10). Nevertheless, as for Ladin, Tussentaal is mainly based on a single variant of the Dutch language, namely Brabantic (Vandekerckhove 2005, 390). Furthermore, according to a growing number of scholars (Grondelaers and van Hout 2011), Tussentaal seems to be undergoing a process of standardisation mainly due to the following two factors. On the one hand, "the exoglossic standard language [Dutch], which was imported from the Netherlands in the twentieth century to resist the dominant position of French in Belgium, never really won the hearts of Flemish speakers" (Delarue and De Caluwe 2015, 10). On the other hand, the above-mentioned "processes of dialect levelling and dialect loss in the central regions of Brabant and East-Flanders [...] necessitate an informal variety (in between the disappearing dialects and the standard) that indexes regional identity" (Delarue and De Caluwe 2015, 11; Willemyns 2007). In fact, because of these diametrical forces, the emergence of Tussentaal has been also labelled as a process of de-standardisation from standard Dutch (Coupland and Kristiansen 2011) or late 
standardisation "in which standardizing and vernacularizing forces condition, rather than cancel one another" (Jaspers and Van Hoof 2015, 39).

The Tussental example highlights the second and the third issue with regard to standardisation and its relationship with minority language maintenance.

a) Standardisation is a never-ending process so that the 'standardised language' actually constantly evolves, while the society and its institutions tend to adapt more slowly to such changes creating further variation among spoken dialects, 'old' written standard and 'new' oral standard.

b) As exemplified by the fact that Tussentaal has "caused severe irritation on the part of the cultural and educational establishment" (Delarue and De Caluwe 2015, 11), changes to the standard may be met with resistance from various sectors of the language community. Indeed, it has been argued that "the general public keeps a close eye on any variation they perceive as threatening the Standard and will stigmatize such forms quite easily" (Pillière and Lewis 2018, 13; Chapman 2012; Gill 2012; Tieken-Boon van Ostade 2018).

Therefore, standardisation processes have both significant advantages and a series of drawbacks that need to be carefully tackled. As underlined by Lane $(2015,281)$,

Standardisation of minority languages is a complex and contradictory process with conflicting agendas and goals. Therefore, minority language standardisation has more than one side to it; while standardisation may serve to strengthen and empower, it can also cause groups or individuals to become excluded or alienated from arenas where they previously felt at home. Standardisation cannot be seen as an unproblematic process, that merely renders visible what was previously invisible, or powerful those who were once powerless.

The considerations highlighted so far have acquired a new weight in the transnational multilevel dimension of immigration phenomena. In this context, standardisation and language maintenance are indeed influenced by wider processes of de- and re-territorialisation. If the next phase in minority language protection calls for an extension of minority rights to the so-called 'new minorities' (Poggeschi 2010), it is fundamental to comprehend the complexities of old processes in a new environment. 


\section{Dynamics of standardisation in a transnational context: new opportunities}

Some of the dynamics between migration phenomena, standardisation processes and heritage language maintenance are very complex and multifaceted. For this reason, it may be useful to analyse some of its features by resorting to a recent case of standardisation, in particular of orthographic standardisation: the ADLaM script for the Fula language.

First of all, this case is useful to highlight the fact that the phenomenon of transnational migration can influence, if not even accelerate, the process of standardisation or at least initiate it. Indeed, as a process is made of consequential steps, standardisation does not occur all at once. For this reason, a changing linguistic landscape may directly trigger innovations only in some components of a linguistic system, while others may be left untouched or may adapt only at a later stage.

Fula (also known as Fulani, Fulfulde, Fulah, Fulbe, Fallata, Haalpulaaren, Pulaar, Pular, and Peul) is the first language of 25 million Fula people (Agbese 2013, 31) and other related groups such as the Tukulor. From a purely linguistic point of view, it belongs to the family of Niger-Congo languages, precisely to the branch of Senegambian languages and is therefore related to Wolof and Serer. However, since a large part of Fula people are nomadic pastoralists, Fula has spread also in the Sahel region. Furthermore, due to international migration, Fula minorities are now present also in Europe and North America. Although often considered a single language, Fula is actually spoken as a set of social (Noss 1979) and geographic variants (Arnott 1974), in a continuum that stretches from Senegal to Sudan. Due to such geographic conformation, neighbouring variants may share a higher degree of mutual intelligibility than distant ones, while at the poles of the continuum inter-communication and inter-comprehension seem not feasible. In fact, although some scholars think that linguistic differences may be overcome "given a certain degree of intelligence and a brief period of adjustment" (Arnott 1970, 3), "often a translation is needed (particularly between groups of the east and the west), given the fact that the various dialects of Fufulde are greatly influenced by the languages of the neighbouring groups" (Oppong 2002, 3). It has even been claimed that, in some cases, some variants inside the same state could not be mutually intelligible at all (Harrison et al. 2012).

Nevertheless, these divisions have not hindered some forms of recognition and promotion at local level. Although former colonial languages still enjoy a higher status, Fula has been recognised -in its regional variants - as a national language in many African countries 
such as Senegal, Guinea, Gambia, Nigeria, Cameroon and Mali. However, such recognition has not been followed by clear and effective language policies, so that it has still to be determined what the 'national language status' pragmatically entails. In fact, although for some countries there may be positive expectations (Benson and Lynd 2011), attempts to grant official status to national languages have ran "into the problem of lack of books and trained teachers" (Judge 1999, 18) as well as into more general financial and organisational problems, which may be expected from mainly poor countries. Therefore, it seems that national language education is still developed and conducted by small communities and associations (Diallo 2018,57) many of which of religious nature (Jalloh 1997, 59).

Against this background, transnational education has brought to the surface an unresolved issue related to Fula but also to most African languages: the lack of orthographic standardisation. Indeed, although African languages have a rich oral tradition, most of them were confronted with alphabets only in relatively recent times. On the one hand, the Arabic 'Ajami' alphabet has been used for centuries but only in relation to some areas and some peoples, that is, those that adopted the script for studying the Quran. On the other hand, European colonisation introduced the Latin alphabet, which however had to be adapted to unfamiliar sounds with sometimes odd outcomes that may vary from one area to the other according to colonial divisions. For these reasons, the same language may be divided not only by state boundaries but also by orthographic ones: indeed, while speakers of the same language across different countries can often "understand each other without any problems in the spoken form, reading each other's script presents a problem because the language is written with different orthographies in these countries" (Nkolola-Wakumelo 2010, 249).

There have been some internationally sponsored attempts to harmonise African languages. For instance, in 1966 "a meeting of Experts was held in Bamako, Mali [...], to determine the transcriptions and, as far as possible, to unify the alphabets of several national languages of West Africa" (UNESCO 1966, 2). Again, a second group of experts met in Niamey, Niger, in 1978 to examine "some practical applications such as transcription equipment, special keyboards and texts produced in African languages, finally proposing an alphabet called the 'African Reference Alphabet'" (UNESCO 1978, Preface). However, the solutions brought by these meetings were not adopted neither by authorities (Gee 2005, 249) nor by speakers themselves so that there is currently "a widespread incompetence in the standard versions of these languages, standard version representing rural varieties from about a 
century ago and quite unlike the varieties currently spoken in the urban areas" (Pasch 2008, 78).

Therefore, as in the case of many other African languages, Fula people still use the modified versions of either 'Ajami' or Latin scripts with all the above-mentioned issues. Actually, besides the international attempts of Bamako and Niamey, some alternative scripts like Fula Dita and Fula Ba were devised from the late 1950s to the mid-1960s. However, as in the case of the African Reference Alphabet, they did not gain acceptance by Fula speakers (Kelly 2018), who still preferred to use local orthographic variants.

Given this history of long-lasting orthographic divisions and failed standardisation attempts, it would seem inevitable that each new solution will face the same destiny. However, new factors have entered the equation, changing modes and places where languages are used and developed.

In the late 1980s, two Guinean teenagers, Ibrahima and Abdoulaye Barry, invented a brand-new alphabet to write Fula/Pular. Originally called simply Bindi Pular (Pular script), it comprised 34 letters (28 plus 6 letters to render borrowed words) and 10 numerals written right to left. They started to teach it firstly to their sister and then in a local market, collecting comments and issues to help the development process. Some years later, while attending the University in Conakry (the capital city of Guinea), they started a group called Winden Jangen (meaning 'writing and reading') to promote and improve their invention by writing teaching materials by hand and distributing them to friends. Then, Abdoulaye moved to the US to pursue a master's degree while Ibrahime continued to teach Fula in Guinea. However, the new script began slowly to spread among the Fula people beyond Guinea in Senegal, Gambia, Sierra Leone, Nigeria and Ghana. It was then labelled ADLaM, an acronym derived from the first four letters of the alphabet (A, D, L, M) and stands for Alkule Dandayde Leñol Mulugol, that is, 'the alphabet that will prevent people from being lost'. At this point, the Barry brothers reunited in the US, where they realised that to fully exploit ADLaM's potential, the next step had to be its computerisation. In the next few years, and with the help and contribution of American scholars, designers and corporate managers, they worked on adding ADLaM to Unicode (Everson 2014), a character encoding standard that enjoys widespread acceptance. In 2016, they finally succeeded in their efforts and ADLaM is now supported by most operating systems and devices, while its use is constantly increasing among Fula-speakers, especially in West Africa. At the same time, Winden Jangen has now spread over different countries and continents, promoting "literacy 
and education in Africa and around the world by providing access to learning and information through alphabetization using the ADLaM Script, supporting local educational initiatives and providing material and financial assistance to ADLaM schools and libraries in remote communities" (Winden Jangen 2012).

Therefore, in ADLaM's story, migration itself becomes a driving force behind language maintenance and language revival both in the native and in the host country. Indeed, it may be impossible to tell whether ADLaM would have received such widespread acceptance if the Barry brothers had remained in Conakry. However, it can be undoubtedly claimed that Abdoulaye and Ibrahima have received fundamental help in their project from various experts in the US and that the 'Unicode process' was conceived, developed and carried out thanks to opportunities and resources found in the US. Furthermore, and more broadly, the very processes of international migration of Fula speakers contributed to the adoption of a standard script. Since they live in different states and continents and they often come from different countries of West Africa, Fula speakers need more than ever a standardised language to easily and effectively communicate between each other.

Along these lines, it can be argued that the very nature of migration as a de-territorialising phenomena has coupled with the means and expertise encountered in different countries by migrants in their newly acquired role of language 'technicians' or 'developers', as exemplified by ADLaM's addition to Unicode. In fact, the adoption of a standard script is strongly influenced by the use of the internet, in particular of social media and instant messaging apps. In fact, much of the communication is now conducted through such media, while online resources can be used to reach scattered communities of speakers, thus making for instance language education available to a wider audience regardless the presence of a nearby educational institution. Furthermore, it cannot be denied that books, texts and generally the literature of a given culture are now shared mainly in the electronic format. Although it must be underlined that the modified Latin and Ajami alphabets were also added to Unicode long before the design of ADLaM, these scripts however greatly vary from one country to the other, thus impairing or impeding communication in an increasingly transnational scenario. Indeed, if local communication among a restricted or even domestic circle may still be conducted with older scripts, the possibility that ADLaM may become the standard in the international migration scenario would likely lead to its adoption also in other context for reasons of convenience. 
Furthermore, the ADLaM's case highlights again the low rate of success of solutions brought by external non-native language speakers. In fact, in contrast to what was done in Bamako and Niamey, the development and increasing success of ADLaM is an example of a real bottom-up process. On the one hand, the UNESCO conferences, and thus the African Reference Alphabet, were gatherings of academics and politicians - but also missionaries- who certainly knew the technical/linguistic issues of standardisation but who also ended up creating solutions that worked perfectly only on paper. Their lack of success may have derived righty from the adopted top-down approach, so that people did not feel incentivised to learn a new script that has been devised by a small circle of unmandated representatives and could be imposed by state authorities without any kind of democratic consultation. On the other hand, ADLaM was made by Fula speakers for Fula speakers and was fine-tuned in over a decade of use between Fula speakers. It was the outcome of a relatively small but surely democratic process, especially since the creation of the Winden Jangen group. It was also adopted without any imposition from governmental authorities, spreading in the Fula language community by word of mouth. It is therefore undoubtedly felt as something that belongs to Fula speakers, an undeniable product of its cultural activities.

However, all that glitters is not gold. As pointed out above, "standards potentially define, enable, constrain, emancipate and also exclude users" (Lane 2015, 281). Indeed, ADLaM originated in a very specific linguistic environment, namely that of Conakry Fula-speakers. Consequently, it has spread very rapidly mostly among this linguistic environment. Instead, speakers of other variants of Fula and generally non-Guineans have been (at least initially) excluded from such a process of bottom-up standardisation. Although, according to some of its proponents, ADLaM is spreading throughout the Fula language community, its specific geographic origin can arguably translate in the future imposition of 'Guinean Fula' as the supra-dialectal standard, excluding other variants from the 'label of correctness' and eventually contributing to a loss of linguistic diversity. In any case, it is still very debatable whether orthographic standardisation through ADLaM can help intelligibility between the most different Fula variants or even trigger a deeper process of standardisation in grammar, spelling, word choice and pronunciation. It may be argued that Conakry Fula may eventually become the reference dialect towards which other variants may orientate, as happened for some European dialects (Cerruti and Regis 2015). Nevertheless, for the moment, its standardising influence seems to have had an effect only on Western variants. 
However, standardisation processes do not work in a single direction. Indeed, migration phenomena can also trigger unexpected dynamics of language choice that favour de- and re-standardisation processes.

\section{Dynamics of re-standardisation in a transnational context: a matter of choice}

As highlighted before, heritage language is an umbrella term that includes very different languages. For instance, while Fula is a minority language with very small recognition also in its countries of origin and, above all, with no recognised and fully accepted standard, Chinese is a standardised official language in its country of origin, spoken by more than a billion people and gaining increasingly functional appeal thanks to global economic processes. Or, is it?

De facto, Chinese is a very wide linguistic family comprising hundreds of variants with various degrees of mutual intelligibility (Norman 2003). Among these, the Mandarin linguistic group is the most spoken and, among this group, the Beijing dialect is the basis upon which Standard Chinese -also known as Modern Standard Mandarin - has been based and developed as the main official language of the People's Republic of China.

Therefore, as Fula as a heritage language may take the form of its different variants according to the geographical origin of its speakers, so does Chinese, since both terms essentially indicate dialect continua, although only Chinese includes a standardised variant. However, such a difference does not always constitute an advantage for heritage language maintenance. Actually, standardisation, when coupled with official recognition, fosters widespread linguistic pre-assumptions that may run counter the needs and claims of native speakers.

Since Standard Mandarin is the official language of China, it can be very tempting to equate Chinese heritage language maintenance with, for example, standard Mandarin education or the translation of public documents in such language. And as a matter of fact, this is the best solution in many cases. Being standard Mandarin the most spoken variant of Chinese and basically the lingua franca of China, services and education provided in this language can reach a wider and more diverse audience, such as that, for instance, of Chinese heritage language communities in Europe. However, this is not always the case.

In some instances, immigrants may come from a very specific region, thus creating a relatively linguistically homogeneous community 
in the country of residence. As highlighted by Nic Craith $(2006,156)$, this is the case for Chinese-speakers of Northern Ireland:

The high proportion of emigrants from Hong Kong means that some eighty-ninety per cent of that community speaks Cantonese. Emigrants from South China, Macao and Malaysia and a number from Vietnam who arrived in the 1970s also speak Cantonese. Some 10-20 per cent of the Chinese community in Northern Ireland speaks Mandarin and Fujianese while a small proportion (mainly elderly members) speaks Hakka. The predominance of Cantonese among the Chinese community in Northern Ireland means that the complex rather than the simplified written form of Chinese is most commonly used (Holder 2003, 31).

Therefore, it can be inferred that, in this case, hypothetical policies of heritage language maintenance and minority accommodation - such as mother tongue tuition or translations of administrative materials - should be carried out predominately in Cantonese to accommodate the language needs of the majority of this specific territorialised immigrant community.

However, the choice between standardised and un-standardised variants is not always a matter of numbers and geographic origin, but also of culture. For instance, Modern Standard Arabic (MSA) is mainly a written language used in formal situations or in media broadcasts, while local variants of the various regional Arabic dialect groups are preferred in daily oral communication. Therefore, there has been some debate on whether Arabic as a heritage language should take the form of local variants or of MSA (Nic Craith 2006, Hillman 2019). Indeed, few programmes of colloquial Arabic as heritage language have actually been successfully received by users (Caubet 2001: 268). However, MSA is the language of schooling in most countries of origin of Arabic heritage language communities. Instead, colloquial variants are not fully standardised for written purposes. Furthermore, although MSA is "socially neutral and unmarked with respect to the speakers" class" (Ibrahim 1986, 124-125), "native speakers who know the local vernaculars only are considered illiterate and have low status in the society" (Alshamrani 2012, 59). These features contribute to, at least, three issues concerning Arabic heritage language education.

a) Institutional support from the country of residence has focused almost only on MSA for political reasons: MSA is not bound to specific national identities and has for instance been publicised as a 'Mediterranean language' (Evers 2018).

b) Given that mainstream Arabic language education is normally conducted in MSA, there is still a lack of teaching staff and 
educational material in colloquial variants, as well as a clear path for an integrative approach (Chekayri 2014).

c) MSA is based and developed on Classic Arabic (CA) - the language of the Qur'an - and has therefore a very strong religious value, which is often emphasised in contexts of migration due to perceived dynamics of 'westernisation'. Therefore, "the classical variety [and its modern counterpart], because of its esteemed religious status, is more likely to persist -but perhaps more in symbolic than communicative functions" (Ferguson 2013, 132).

Finally, it is important to highlight that linguistic attitudes towards different varieties may differ between generations. While first generations may prefer standard varieties for their perceived higher socio-cultural value, second generations may feel dissatisfied with their artificiality and show an emotional attachment to the varieties they orally learned at home (Ferguson 2013; Evers 2018).

\section{Conclusion: from a hybrid understanding to a hybrid practice}

The aim of this collection of cases and examples has been to highlight how standardisation processes and linguistic variation may relate to projects of minority/heritage language maintenance. Although some dynamics may be common to all instances regardless of the context of autochthony or migration and of the (geo-)linguistic characteristics of the language, other dynamics are case-specific and need to be tackled singularly by law and policymakers.

For this reason, and as briefly argued before, language policies should be adapted to the peculiarities of a given linguistic context, while also obtaining an early approval by the targeted language community and after having gathered and analysed speakers' language attitudes (Rasom 2011). For instance, by decentralising policy-making competences to regional or local minority bodies, governments can better adapt general provisions into specific linguistic landscapes (Penasa 2011). In the case of 'new minorities', this may practically mean including cultural and linguistic associations in the policymaking process, as well as in that of policy implementation, enhancing coordination among different levels of government.

However, the complexities of linguistic variation and the consequent linguistic choices of language users are often very hard to grasp and translate into solid and effective policies. As highlighted in the previous 
pages, linguistic dynamics are indeed not only context specific but may vary also between generations and because of cultural processes. For this reason, what may have been a reasonable and thoughtful policy choice for a given language community can become a constraining factor in a relatively short period of time, especially in a highly variable environment such as that shaped by migration phenomena.

Therefore, it may seem that gaining a hybrid understanding of language, of its internal variation and of processes of standardisation can hardly be directly equated to a development towards a more inclusive perspective on language rights and policies.

However, complex issues may be tackled with adaptative solutions. In other words, if language, language belonging and multilingualism have been approached with hybrid understandings, the same should be done with policies.

Indeed, the fields of linguistics and pedagogy have already indicated a path of inclusion. Theoretical and empirical studies have highlighted the positive instrumental impact of including non-standard dialects —alongside minority languages - in education (Siegel 1999; Papapavlou and Pavlou 2007; Tegegne 2015; Leonardi 2016). In fact, "in some countries there is a long tradition of sociolinguists and dialectologists attempting to make their contrastive analyses of different dialects available to schoolteachers, often motivated by the belief that a contrastive analysis of a dialect and the standard variety can help teachers distinguish genuine errors from cases of language transfer, and teach schoolchildren some of the systematic differences between the dialect and the standard" (Cheshire 2007, 15). Furthermore, the use of dialects in an institutional environment may legitimise diversity, contrasting the alienating centrifugal forces of the standardisation process. Other studies have pointed out the advantages of integrative approaches to minority and heritage language education that, for instance, allow or even stimulate hybrid linguistic practices such as

a) translanguaging (García and Wei 2014), understood as "both the ability of multilinguals to shuttle very easily between languages, without regard for socially and politically defined boundaries, and as a pedagogy through which teachers, by using scaffolding methods, enable children to see and use all of their languages for learning" (Ticheloven et al. 2019, 1-2),

b) and code-switching (Alsahafi 2019), which signifies "the alternation between two or more language varieties in the same sentence or piece of discourse" (Albirini and Chakrani 2017, 320). 
Such an approach re-positions speakers at the centre of language policies. In fact, acquiring a deeper understanding of processes of standardisation and linguistic variation does not translate into simply officialising a given variant, but in legitimising diversity and hybridity. For instance, resorting again to the case of Arabic, inclusive measures may not be those that recognise the teaching of Colloquial Arabic(s), but those that better mirror the natural hybrid linguistic practices of Arabic speakers, thus complementing MSA education with the use of oral variants. Indeed, "we should understand language not as a fixed and stable structure (de Saussure's langue), but rather focus on communication as a messy human behaviour that adapts and flexes with new pressures, reflecting identity and helping create it (de Saussure's parole)" (Wright 2018, 651-652).

Therefore, a hybrid understanding of language fosters a more inclusive perspective on language rights and policies in the same way as the recognition of multilingualism and language belonging have been recognised to do. However, such awareness needs to be accompanied by a change in scope, shifting from viewing linguistic landscapes as Modigliani paintings (Gellner 1983; Van Parijs 2011) with clearly demarcated boundaries to a colour sensibility similar to that of Monet and his coloured shadows.

Finally, inclusive perspectives originate from inclusive approaches. The globalising world is an ever-complicating environment that should be analysed with a comprehensive and coordinated approach. There are plenty of issues related to language use, protection and promotion that have been elaborated in the fields of linguistics, the social sciences, psychology, economics, legal studies, etc., and are still relegated to small circles of monodisciplinary debates. In this context, disciplines should talk to each other, avoiding monolithic or dogmatic concepts and allowing themselves to be challenged from external points of view.

\section{References}

ACFC. 2012. The Language Rights of Persons Belonging to National Minorities Under The Framework Convention, Thematic Commentary no. 3, ACFC/44DOC(2012)001 rev

Agbese, Aje-Ori. 2013. «Fulani». In Native Peoples of the World. An Encyclopaedia of Groups, Cultures, and Contemporary Issues, edited by Steven Danver, 31-32. London: Routledge.

Albirini, Abdulkafi, and Brahim Chakrani. 2017. "Switching codes and registers: An analysis of heritage Arabic speakers' sociolinguistic competence». International Journal of Bilingualism 21(3): 317-339. 
Alcalde, Javier. 2018. "Linguistic Justice: An Interdisciplinary Overview of the Literature». In Language Policy and Linguistic Justice. Economic Philosophical and Sociolinguistic Approaches, edited by Michele Gazzola, Torsten Templin and Bengt-Arne Wickström, 65-149. Cham: Springer.

Alsahafi, Morad. 2019. "Language Maintenance and Heritage Language Education: The Case of a Weekend Arabic School in New Zealand». International Journal of Applied Linguistics and English Literature 8(2): 21-29.

Alshamrani, Hassan. 2012. "Diglossia in Arabic TV stations». Journal of King Saud University - Languages and Translation 24(1): 57-69.

Anderson, Benedict. 1983. Imagined Communities: Reflections on the Origins and Spread of Nationalism. London: Verso.

Arnott, David W. 1970. The Verbal and Nominal Systems of Fula. Oxford: Oxford University Press.

Arnott, David W. 1974. "Some Aspects of the Study of Fula Dialects». Bulletin of the School of Oriental and African Studies 37(1): 8-18.

Bagna, Carla, Sabrina Machetti, and Massimo Vedovelli. 2003. «Italiano e lingue immigrate: verso un plurilinguismo consapevole o verso varietà di contatto?» In Ecologia linguistica. Atti del XXXVI congresso internazionale di studi della Società di Linguistica Italiana, edited by Ada Valentini, Piera Molinelli, Pierluigi Cuzzolin, and Giuliano Bernini, 201-222. Roma: Bulzoni.

Bauböck, Rainer. 1996. "Cultural Minority Rights for Immigrants». The International Migration Review 30(1): 203-250.

Benson, Carol, and Mark Lynd. 2011. "National languages in education in Guinea-Conakry: re-emancipation in progress?» International Journal of the Sociology of Language 209: 113-129.

Bloomfield, Leonard. 1933. Language. London: George Allen \& Unwin.

Caubet, Dominique. 2001. "Maghrebine Arabic in France». In The Other Languages of Europe: Demographic, Sociolinguistic and Educational Perspectives, edited by Guus Extra and Durk Gorter, 260-277. Clevedon: Multilingual Matters.

Cenoz, Jasone, and Durk Gorter. 2014. «Focus on Multilingualism as an Approach in Educational Contexts». In Heteroglossia as Practice and Pedagogy. Educational Linguistics, vol 20, edited by Adrian Blackledge and Angela Creese, 239-254. Dordrecht: Springer.

Cerruti, Massimo, and Riccardo Regis. 2015. «The Interplay between Dialect and Standard: Evidence from Italo-Romance». In Language variation. European Perspectives $V$, edited by Eivind Torgersen, Stian Hårstad, Brit Mæhlum and Unn Røyneland, 55-68. Amsterdam: John Benjamins.

Chapman, Don. 2012. "You say nucular; I say your stupid: Popular prescriptivism in the politics of the United States». In The Languages of Nation: Attitudes and Norms, edited by Carol Percy and Mary Catherine Davidson, 192-210. Clevedon: Multilingual Matters.

Chekayri, Abdellah. 2014. "The Challenges of the Shift from a Modern Standard Arabic-only Approach to an Integrative Approach». In Arabele 2012: Enseñanza y aprendizaje de la lengua árabe = Teaching and Learning the 
Arabic Language, edited by Victoria Aguilar, Miguel Ángel Manzano, Luis Miguel Pérez Cañada, Waleed Saleh and Paula Santillán Grimm, 45-70. Murcia: Universidad de Murcia.

Cheshire, Jenny. 2007. «Dialect and Education: Responses from Sociolinguists». In Sociolinguistic and Pedagogical Dimensions of Dialects in Education, edited by Andreas Papapavlou and Pavlos Pavlou, 14-33. Newcastle: Cambridge Scholars Publishing

Cho, Grace, Stephen Krashen, and Fay Shin. 2004. «What do we know about heritage languages? What do we need to know about them?» Multicultural Education 11(4): 23-26.

Coupland, Nikolas, and Tore Kristiansen. 2011. «Critical perspectives on language (de)standardisation». In Standard languages and language standards in a changing Europe, edited by Tore Kristiansen and Nikolas Coupland, 11-38. Oslo: Novus.

Costa, James, Haley de Korne and Pia Lane. 2017. "Standardizing Minority Languages: Reinventing Peripheral Languages in the 21st Century». In Standardizing Minority Languages. Competing Ideologies of Authority and Authenticity in the Global Periphery, edited by Pia Lane, James Costa and Haley De Korne, 1-23. New York: Routledge.

Craig, Elizabeth. 2016. "Who Are The Minorities? The Role of the Right to Self-Identify within the European Minority Rights Framework». Journal on Ethnopolitics and Minority Issues in Europe 15(2): 6-30.

Delarue, Steven, and Johan De Caluwe. 2015. «Eliminating social inequality by reinforcing standard language ideology? Language policy for Dutch in Flemish schools». Current issues in language planning 16(1-2): 8-25.

De Schutter, Helder. 2007. Language policy and political philosophy. On the emerging linguistic justice debate. Language Problems \& Language Planning 31(1): 1-23.

Deumert, Ana, and Wim Vandenbussche. 2003. "Research directions in the study of language standardization». In Germanic Standardizations: Past to Present, edited by Ana Deumert and Wim Vandenbussche, 455-469. Amsterdam: John Benjamins.

Diallo, Ibrahima. 2018. Geopolitics of French in Francophone Subsaharian Africa: Attitudes, Language use and Identities. Newcastle upon Tyne: Cambridge Scholars Publishing.

Evers, Cécile. 2018. «Not Citizens of a Classical Mediterranean: Muslim Youth from Marseille Elude a Linguistic Gentrification by the French State». Signs and Society 6(2): 435-474.

Everson, Michael. 2014. Revised proposal for encoding the Adlam script in the SMP of the UCS. International Organisation for Standardisation, L2/14-219R.

Ferguson, Charles A. 1996. "Standardization as a form of language spread». In Sociolinguistic Perspectives: Papers on Language in Society, 1959-1994, edited by Thom Huebner, 189-199. Oxford: Oxford University Press.

Ferguson, Gibson R. 2013. "Language practices and language management in a UK Yemeni community». Journal of Multilingual and Multicultural Development 34(2): 121-135. 
García, Ofelia and Li Wei. 2014. Translanguaging: Language, Bilingualism and Education. Basingstoke: Palgrave Macmillan.

Gellner, Ernest. 1983. Nations and nationalism. Oxford: Blackwell.

Gee, Quintin. 2005. "Review of script displays of African languages by current software». New Review of Hypermedia and Multimedia 11(2): 247-255.

Gill, Martin. 2012. "Nativeness, authority, authenticity: The construction of belonging and exclusion in debates about English language proficiency and immigration in Britain». In The Languages of Nation: Attitudes and Norms, edited by Carol Percy and Mary Catherine Davidson, 271-291. Clevedon: Multilingual Matters.

Grondelaers, Stefan, and Roeland van Hout. 2011. "The Standard Language Situation in the Low Countries». Journal of Germanic Linguistics 23: 199-243.

Grosjean, François. 1989. «Neurolinguists, beware! The bilingual is not two monolinguals in one person». Brain and Language 36(1): 3-15

Hallen, Harold B., and Michael D. Linn. 1984. «Introduction to Social Dialects and Language Variation». In Dialect and Language Variation, edited by Harold B. Hallen and Michael D. Linn, 237-238. Orlando: Academic Press.

Haugen, Einar. 1966. «Dialect, Language, Nation». American Anthropologist 68(4): 922-935.

Haugen, Einar. 1972. The Ecology of Language. Redwood: Stanford University Press.

Harrison, Annette R., Byron L. Harrison, Michael J. Rueck, and Kendall Isaac. 2012. A Study of Fulfulde Varieties of Eastern Niger: Dialect Intelligibility and Language Attitudes. SIL Electronic Survey Reports. 2012-003. Dallas: SIL International.

Hillman, Sara. 2019. "I'm a Heritage Speaker of the Damascene Dialect of Arabic": Negotiating the Identity Label of Arabic Heritage Language Learner». Heritage Language Journal 16(3): 296-317.

Holder, Daniel. 2003. In Other Words? Mapping Minority Ethnic Languages in Northern Ireland. Belfast: Multi-Cultural Resource Centre.

Hudson, Richard A. 1980. Sociolinguistics. Cambridge: Cambridge University Press.

Ibrahim, Muhammad. H. 1986. «Standard and prestige language: a problem in Arabic sociolinguistics». Anthropological linguistics 28: 115-126

Jalloh, Alusine. 1997. "The Fula and Islamic Education in Freetown, Sierra Leone». The American Journal of Islamic Social Sciences 14(4): 51-68.

Jaspers, Jürgen, and Sarah Van Hoof. 2015. «Ceci N'est Pas Une Tussentaal: Evoking Standard and Vernacular Language Through Mixed Dutch in Flemish Telecinematic Discourse». Journal of Germanic Linguistics 27(1): $1-44$

Jones, Mari C. 1995. «At What Price Language Maintenance? Standardization in Modern Breton». French Studies 49(4): 424-438.

Judge, Anne. 1999. "Voices and Policies». In Francophone Voices, edited by Salhi Kamal, 1-26. Exeter: Elm Bank Publications. 
Kelly, Piers. 2018. «The Invention, Transmission and Evolution of Writing: Insights from the New Scripts of West Africa». In Studi Micenei ed Egeo-Anatolici, Nuova Serie, Supplemento I, Paths into Script Formation in the Ancient Mediterranean, edited by Silvia Ferrara and Miguel Valério, 189-209. Roma: Edizioni Quasar.

Kloss, Heinz. 1967. «Abstand languages and Ausbau languages». Anthropological linguistics 9: 90-101.

Lane, Pia. 2015. "Minority language standardisation and the role of users». Language Policy 14: 263-283.

Leonardi, Maria Maya Victoria. 2016. Bilingualism or Trilingualism? Social versus linguistic views: Evidence from the Germanic-speaking language group in South Tyrol (Italy). PhD Dissertation, Bangor University

Makarova, Elena. 2014. "Courses in the language and culture of origin and their impact on youth development in cultural transition: A study amongst immigrant and dual-heritage youth in Switzerland». In Rethinking heritage language education, edited by Peter P. Trifonas and Themistoklis Aravossitas, 89-114. Cambridge: Cambridge University Press.

Marko, Joseph, and Roberta Medda-Windischer. 2018. «Language Rights and Duties for New Minorities: Integration through Diversity Governance». In Language Policy and Conflict Prevention, edited by Iryna Ulasiuk, Laurenţiu Hadîrcă, and William Romans, 251-284. Leiden: Brill Nijhoff.

Maxwell, Alexander. 2018. "When Theory is a Joke: The Weinreich Witticism in Linguistics». Beiträge zur Geschichte der Sprachwissenschaft 28(2): 263-292.

Medda-Windischer, Roberta, and Andrea Carlà. 2015. «Introduction». In Migration and Autonomous Territories: The Case of South Tyrol and Catalonia, edited by Roberta Medda-Windischer and Andrea Carlà, 1-26. Leiden: Koninklijke Brill.

Medda-Windischer, Roberta. 2017. «Old and New Minorities: Diversity Governance and Social Cohesion from the Perspective of Minority Rights». Acta Universitatis Sapientiae, European and Regional Studies 11: 25-42.

Mesthrie, Rajend. 1999. "Language loyalty». In Concise Encyclopedia of Educational Linguistics, edited by Bernard Spolsky, 42-47. Amsterdam: Elsevier.

Milroy, James, and Lesley Milroy. 1985. Authority in language: investigating language prescription and standardisation. London: Routledge.

Milroy, James. 2006. "The Ideology of the Standard Language». In The Routledge Companion in Sociolinguistics, edited by Carmen Llamas, Louise Mullany and Peter Stockwell, 133-139. London: Routledge.

Nic Craith, Máiréad. 2006. Europe and the Politics of Language: Citizens, Migrants and Outsiders, New York: Palgrave Macmillan.

Nkolola-Wakumelo, Mildred. 2010. "Challenges to scholarly Africanlanguage Publishing». In Scholarly Publishing in Africa. Opportunities and Impediments, edited by Solani Ngobeni, 237-258. Pretoria: Africa Institute of South Africa.

Norman, Jerry. 2003. "The Chinese dialects: phonology». In The Sino-Tibetan Languages, edited by Graham Thurgood and Randy J. La Polla, 72-83. London: Routledge. 
Noss, Philip A. 1979. «Fula: A Language of Change». In Readings in Creole Studies, edited by lan F. Hancock, 173-188. Philadelphia: John Benjamins Publishing.

Oppong, Yaa P. A. 2002. Moving Through and Passing On: Fulani Mobility, Survival and Identity in Ghana. New Brunswick: Transaction Publishers.

Orioles, Vincenzo. 2007. «Modelli di tutela a confronto: promuovere la ricerca e la formazione o assecondare la deriva burocratica». In Minoranze linguistiche. Prospettive, strumenti, territori, edited by Carlo Consani and Paola Desideri, 327-335. Roma: Carocci.

OSCE HCNM. 2012. The Ljubljana Guidelines on Integration of Diverse Societies \& Explanatory Note. The Hague: OSCE HCNM

Panzeri, Lino. 2016. La tutela dei diritti linguistici nella Repubblica delle autonomie, Milano: Giuffrè.

Papapavlou, Andreas, and Pavlos Pavlou, eds. 2007. Sociolinguistic and Pedagogical Dimensions of Dialects in Education. Newcastle: Cambridge Scholars Publishing.

Pasch, Helma. 2008. "Competing scripts: the introduction of the Roman alphabet in Africa». International Journal of the Sociology of Language 191: 65-109.

Pauwels, Anne. 2016. Language Maintenance and Shift. Cambridge: Cambridge University Press.

Penasa, Simone. 2011. «ll sistema scolastico trentino e I'apprendimento della e nella lingua propria delle minoranze linguistiche: un approccio olistico e differenziato». In Didattica delle lingue locali. Esperienze di ladino, mòcheno e cimbro nella scuola e nell'Università, edited by Patrizia Cordin, 155-172. Milano: Franco Angeli.

Pillière, Linda, and Diana Lewis, 2018. «Revisiting standardisation and variation». E-rea - Revue électronique d'études sur le monde anglophone 15(2). Accessed August 19, 2020. https://journals.openedition.org/erea/6391

Poggeschi, Giovanni. 2010. I diritti linguistici. Roma: Carocci

Polinsky, Maria, and Olga Kagan. 2007. "Heritage languages: In the "wild" and in the classroom». Language and Linguistics Compass 1(5): 368-395.

Rasom, Sabrina. 2011. "Varietà locali e standardizzazione. Esperienze nelle scuole ladine». In Didattica delle lingue locali. Esperienze di ladino, mòcheno e cimbro nella scuola e nell'Università, edited by Patrizia Cordin, 23-38. Milano: Franco Angeli.

Riera Gil, Elvira. 2016. Why Languages Matter to People. Communication, identity and justice in western democracies. The case of mixed societies. Barcelona: Generalitat de Catalunya, Institut d'Estudis de I'Autogovern.

Saint-Jacques, Bernard. 1979. "The languages of immigrants». In The languages of Canada, edited by in Jack K. Chambers, 207-225. Ottawa: Marcel Didier.

Siegel, Jeff. 1999. «Stigmatized and Standardized Varieties in the Classroom: Interference or Separation?» TESOL Quarterly 33(4): 701-728.

Slaughter, Mary M. 1982. Universal Languages and Scientific Taxonomy in the Seventeenth Century. Cambridge: Cambridge University Press. 
Tegegne, Wondimu. 2015. «The Use of Dialects in Education and Its Impacts on Students' Learning and Achievements». Education Journal 4(5): 263-269.

Ticheloven, Anouk, Elma Blom, Paul Leseman and Sarah McMonagle. 2019. "Translanguaging challenges in multilingual classrooms: scholar, teacher and student perspectives». International Journal of Multilingualism. Doi: 10.1080/14790718.2019.1686002

Tieken-Boon van Ostade, Ingrid. 2018. "The grammatical margins of class». In Standardising English: Norms and Margins in the History of the English Language, edited by Linda Pillière, Wilfrid Andrieu, Valérie Kerfelec and Diana Lewis, 193-212. Cambridge: Cambridge University Press.

Trifonas, Peter P., and Themistoklis Aravossitas. 2018. "Heritage and Language: Cultural Diversity and Education». In Handbook of Research and Practice in Heritage Language Education, edited by Peter P. Trifonas and Themistoklis Aravossitas, 3-25. New York: Springer.

UNESCO. 1966. Meeting of a Group of Experts for the Unification of Alphabets of National Languages. Final Report.

UNESCO. 1978. Proceedings of the meeting of experts on the transcription and harmonization of African languages.

UN HRC. 2020. Report of the Special Rapporteur on Minority Issues, Dr. Fernand de Varennes - Education, language and the human rights of minorities, $\mathrm{A}$ $\mathrm{HRC} / 43 / 47$.

Vandekerckhove, Reinhild. 2005. «Belgian Dutch versus Netherlandic Dutch: New patterns of divergence? On pronouns of address and diminutives». Multilingua 24: 379-397.

van Parijs, Philippe. 2011. Linguistic justice for Europe and for the world. Oxford: Oxford University Press.

van Wyk, E. B. 1992. "The Concept of "Standard Language"». South African Journal of African Languages 12:sup1: 23-34.

Vertovec, Steven. 2007. "Super-diversity and its implications». Ethnic and Racial Studies 30(6): 1024-1054.

Waldron, Jeremy. 1992. "Minority Cultures and the Cosmopolitan Alternative». University of Michigan Journal of Law Reform 25(3-4): pp. 751-793.

Wardhaugh, Ronald. 2006. An Introduction to Sociolinguistics. Fifth Edition. Oxford: Blackwell.

Weinreich, Max. 1945. "Der yivo un di problemen fun undzer tsayt». Yivobleter 25: 3-18.

Winden Jangen. 2012. Winden Jangen ADLaM. If Language is the vehicle of culture, Writing is the vehicle of language. Accessed February 15, 2020. https://www.windenjangen.org/

Wiley, Terrence. 2005. «The reemergence of heritage and community language policy in the U.S. national spotlight». The Modern Language Journal 89(4): 594-601.

Willemyns, Roland. 2007. «De-standardization in the Dutch language territory at large». In Standard, variation and language change in Germanic languages, edited by Christian Fandrych and Reiner Salverda, 267-279. Tübingen: Gunter Narr. 
Wright, Sue. 2007. «The Right to Speak One's Own Language: Reflections on Theory and Practice». Language Policy 6(2): 203-224.

Wright, Sue. 2015. «What is language? A response to Philippe van Parijs». Critical Review of International Social and Political Philosophy 18(2): 113-130.

Wright, Sue. 2018. «Planning Minority Language Maintenance: Challenges and Limitations». In The Oxford Handbook of Endangered Languages, edited by Benneth L. Rehg and Lyle Campbell, 637-658. Oxford: Oxford University Press.

Yeung, Alexander Seeshing, Herbert W. Marsh, and Rosemary Suliman. 2000. "Can two tongues live in harmony: Analysis of the National Education Longitudinal Study of 1988 (NELS88) longitudinal data on the maintenance of home language». American Educational Research Journal 37(4): 1001-1026. 


\section{Copyright}

Deusto Journal of Human Rights / Revista Deusto de Derechos Humanos is an Open Access journal; which means that it is free for full and immediate access, reading, search, download, distribution, and reuse in any medium only for non-commercial purposes and in accordance with any applicable copyright legislation, without prior permission from the copyright holder (University of Deusto) or the author; provided the original work and publication source are properly cited (Issue number, year, pages and DOI if applicable) and any changes to the original are clearly indicated. Any other use of its content in any medium or format, now known or developed in the future, requires prior written permission of the copyright holder.

\section{Derechos de autoría}

Deusto Journal of Human Rights / Revista Deusto de Derechos Humanos es una revista de Acceso Abierto; lo que significa que es de libre acceso en su integridad inmediatamente después de la publicación de cada número. Se permite su lectura, la búsqueda, descarga, distribución y reutilización en cualquier tipo de soporte sólo para fines no comerciales y según lo previsto por la ley; sin la previa autorización de la Editorial (Universidad de Deusto) o la persona autora, siempre que la obra original sea debidamente citada (número, año, páginas y DOI si procede) y cualquier cambio en el original esté claramente indicado. Cualquier otro uso de su contenido en cualquier medio o formato, ahora conocido o desarrollado en el futuro, requiere el permiso previo por escrito de la persona titular de los derechos de autoría. 